\title{
THE CHARACTERISTICS AND MANAGEMENT PROBLEMS OF THE VEGETATION AND FLORA OF THE HUNTINGFIELD AREA, SOUTHERN TASMANIA
}

\author{
by J.B. Kirkpatrick
}

(with two tables, four text-figures and one appendix)

\begin{abstract}
KirKPatrick, J.B., 1999 (31:x): The characteristics and management problems of the vegetation and flora of the Huntingfield area, southern Tasmania. Pap. Proc. R. Soc. Tasm. 133(1): 103-113. https://doi.org/10.26749/rstpp.133.1.103 ISSN 0080-4703. School of Geography and Environmental Studies, University of Tasmania, GPO Box 252-78, Hobart, Tasmania, Australia 7001.

The Huntingfield area has a varied vegetation, including substantial areas of Eucalyptus amygdalina heathy woodland, heath, buttongrass moorland and E. amygdalina shrubby forest, with smaller areas of wetland, grassland and E. ovata shrubby forest. Six floristic communities are described for the area. Two hundred and one native vascular plant taxa, 26 moss species and ten liverworts are known from the area, which is particularly rich in orchids, two of which are rare in Tasmania. Four other plant species are known to be rare and/or unreserved in Tasmania. Sixty-four exotic plant species have been observed in the area, most of which do not threaten the native biodiversity. However, a group of fire-adapted shrubs are potentially serious invaders. Management problems in the area include the maintenance of open areas, weed invasion, pathogen invasion, introduced animals, fire, mechanised recreation, drainage from houses and roads, rubbish dumping and the gathering of firewood, sand and plants.
\end{abstract}

Key Words: flora, forest, heath, Huntingfield, management, Tasmania, vegetation, wetland, woodland.

\section{INTRODUCTION}

The Huntingfield Estate, approximately 400 ha of forest, woodland, heath and pasture to the west of Blackmans Bay, south of Hobart, Tasmania, was purchased by government for housing development. In 1997, most of the remaining natural vegetation in the Huntingfield Estate was proclaimed as the Peter Murrell Nature Reserve and Conservation Area.

Parts of this area have been subject to previous botanical surveys. Kirkpatrick 1977 sampled the heaths of the area and recommended that they be reserved as the only extensive example of the vegetation type near Hobart. Botanical surveys, concentrating on the Coffee Creek area, have been produced by Pyrke (1990) and Duncan \& Duncan (1995). Ziegeler (1994) mapped the distribution of the threatened orchid, Prasophyllum concinnum, in Huntingfield.

The present paper documents the vegetation and the vascular and bryophytic flora of the area, and discusses vegetation management issues in a conservation context.

\section{METHODS}

A rough vegetation map of the estate was drawn up, using a corrected black and white aerial photograph mosiac. Approximately ten sampling locations were placed in each of five mapping units, using a table of random numbers. An extra two sampling sites were located subjectively within a small area of native grassland that was not recognised in the initial mapping. In addition, vascular plant species lists were made for the zones within the small, natural enclosed wetland on the estate.

At each sampling site a $10 \times 10 \mathrm{~m}$ quadrat was laid out. All identifiable vascular plant taxa within this space were noted. The cross-sectional area of trees at $1.3 \mathrm{~m}$ (basal area) was measured using the Bitterlich variable radius technique (Mueller-Dombois \& Ellenberg 1974). The height of the shrub stratum was measured using a tape. The cover of the shrub stratum was estimated using the following classes: $<1 \%, 1-5 \%$, 5-25\%, 25-50\%, 50-75\%, 75-100\%. The species with the most cover in the shrub stratum (dominant species) was noted. If another species had more than half the cover of the dominant one it was noted as a codominant. Altitude, slope (using a clinometer) and aspect (direction of slope, using a compass) were also noted for each quadrat.

While traversing the area from sample location to sample location and at other times, notes were made of the locations and extent of exotic species infestations and of the vegetation type. These observations and coloured aerial photographs (Hobart Area 11.3.95, run 4, 1234-101 and 1234-103) were used to refine the vegetation map and to produce a map of exotic plant infestations. Vegetation mapping seeks to draw boundaries around areas of relative uniformity in colour and texture on aerial photographs, or other imagery, then identify the vegetation characteristics that make each unit different. It does not necessarily result in units that fully correspond with the distributions of floristic groups, because the dominant species in the tree and ground layers do not necessarily control the overall floristic composition (Kirkpatrick \& Dickinson 1986).

An initial sorted table of the species by site data was produced using a computer program, TWINSPAN (Hill 1979). This table was then sorted further to better reveal groups of quadrats with similar species composition and groups of species with similar quadrat distributions. The groups of quadrats are the floristic communities, which can be identified through the presence and absence of groups of species. These are not necessarily congruent with mapping units.

\section{RESULTS}

\section{The Flora}

Two hundred and one native vascular plant taxa have been recorded from the Huntingfield Estate in this and previous studies (appendix 1). Eleven (5.5\%) of these taxa are endemic to Tasmania. The outstanding family in terms of numbers of native species is the Orchidaceae, with 35 species in the 
area, including two Tasmanian endemics, Prasophyllum concinnum and Caladenia atrata. Twenty-six native moss species and ten native liverwort species have also been observed in the area by Tony Moscal (appendix 1). One of the moss species, Archidium stellatum, has not been previously known from Tasmania. However, its identification awaits confirmation.

Sixty-four exotic vascular plant taxa have been observed in the estate (appendix 1). Grasses (Poaceae) and daisies (Asteraceae) constitute a large proportion of these taxa.

\section{The Plant Communities}

Six floristically distinct communities were recognised from the sorted table (table 1). The distributions of the communities are shown in figure 1 . The descriptions below indicate all species occurring in more than $60 \%$ of the quadrats in a particular group, grouped by lifeform. The term graminoid covers sedges, rushes, orchids, lilies and irids. The name of a floristic group includes the combination of species that best differentiate the group from others and the most common structural/dominance vegetation type. Similar vegetation types recognised in the literature are indicated.

\section{Floristic Communities}

(1) Acacia genistifolia-Deyeuxia quadriseta-Goodenia lanata heath/grassland

Trees: Eucalyptus amygdalina

Shrubs: Acacia genistifolia, A. myrtifolia, Ampereaxiphoclada, Epacris impressa, Gonocarpus tetragynus, Hibbertia riparia, Leptospermum scoparium, Leucopogon collinus, Styphelia adscendens

Graminoids: Hypolaena fastigiata, Lepidosperma concavum, Leptocarpus tenax, Schoenus lepidosperma

Grasses: Danthonia spp., Deyeuxia quadriseta, Ehrharta distichophylla, E. stipoides, Stipa spp.

Herbs: Goodenia lanata, Helichrysum scorpioides

Ferns: Pteridium esculentum

Most similar vegetation type: Lepidosperma concavumCassytha glabella-Gonocarpus tetragynus heath (Kirkpatrick 1977)

This community is defined by the presence of species groups $A$ and $B$ and the absence of species groups $\mathrm{C}, \mathrm{F}-\mathrm{H}$ and $\mathrm{J}-\mathrm{N}$ (table 1). It occurs in well-drained places where a fine-textured soil horizon is close to or at the surface. It lacks a dense shrub stratum and is relatively rich in grasses and herbs, possibly a reflection of a higher nutrient status of its soils than adjacent communities on deep sands. Acacia genistifolia is the most common dominant species. However, some quadrats in this groups are dominated by Stipa mollis, which is particularly striking during its flowering season. Trees, where they occur, are very sparse.

(2) Eucalyptus amygdalina-Baeckea ramosissima-Tetratheca labillardierei heathy woodland

Trees: Eucalyptus amygdalina

Shrubs: Allocasuarina monilifera, Amperea xiphoclada, Aotus ericoides, Baeckea ramosissima, Bossiaea cinerea, Epacris impressa, Gonocarpus tetragynus, Leptospermum scoparium, Leucopogon collinus, L. ericoides, Pimelea linifolia

Parasitic climbers: Cassytha pubescens

Graminoids: Hypolaena fastigiata, Schoenus lepidosperma

Herbs: Stylidium graminifolium

Ferns: Pteridium esculentum
Most similar vegetation types: Heathy Eucalyptus amygdalina coastal forest (Duncan \& Brown 1985)

This community is defined by the presence of species in groups D-I and the absence of species in groups A, B and J-N (table 1). There are no species that are both largely confined to this community and present in most of its quadrats. This is the most widespread vegetation type in the estate. It is usually a woodland dominated by E. amygdalina, with a dense understorey of small-leaved shrubs and bracken less than $2 \mathrm{~m}$ tall. It occurs on welldrained sites on deep, leached sand.

(3) Allocasuarina monilifera-Gymnoschoenus sphaerocephalusDillwynia glaberrima heath

Trees: Eucalyptus amygdalina

Shrubs: Allocasuarina monilifera, Amperea xiphoclada, Aotus ericoides, Baeckea ramosissima, Bossiaea cinerea, Dillwynia glaberrima, Epacris impressa, E. lanuginosa, Hibbertia acicularis, Leptospermum scoparium, Leucopogon collinus, L. ericoides, Pimelea linifolia

Parasitic climbers: Cassytha glabella, C. pubescens

Graminoids: Gymnoschoenus sphaerocephalus, Hypolaena fastigiata, Lepidosperma filiforme, Leptocarpus tenax

Herbs: Stylidium graminifolium

Ferns: Pteridium esculentum

Most similar vegetation type: Schoenus lepidosperma-Epacris lanuginosa-Empodisma minus heath (Kirkpatrick 1977)

This community is defined by the presence of species in groups D-J and the absence of species in groups A-C and $\mathrm{K}-\mathrm{N}$. There are no species that are both largely confined to this community and present in most of its quadrats. The community consists mostly of heath, marginal to sedgeland. It occurs on more poorly-drained sites than the heaths in group 1. Trees, where present, are usually sparse.

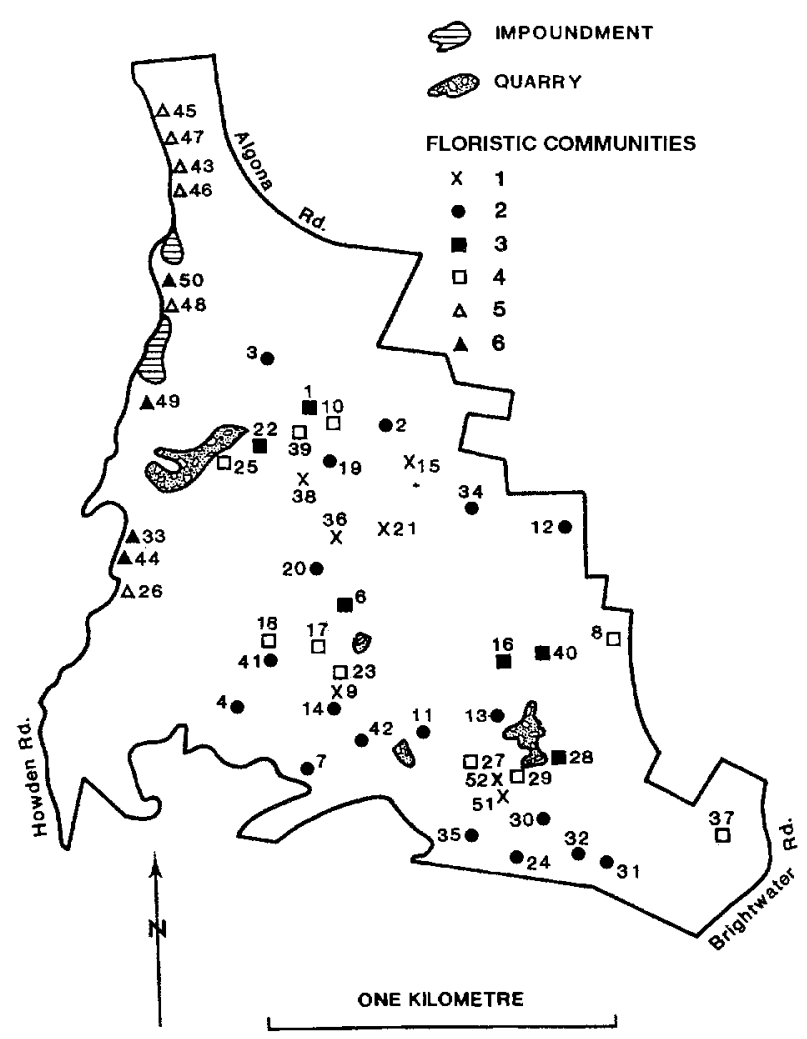

FIG. 1 - The distribution of quadrats in the six floristic communities 
(4) Melaleuca squarrosa-Gymnoschoenus sphaerocephalusGleichenia dicarpa sedgeland/heath/fernland

Trees: Eucalyptus amygdalina

Shrubs: Aotus ericoides, Dillwynia glaberrima, Epacris lanuginosa, Leptospermum scoparium, Melaleuca squarrosa, Sprengelia incarnata

Graminoids: Gymnoschoenus sphaerocephalus, Leptocarpus tenax, Lepyrodia tasmanica, Patersonia fragilis, Schoenus lepidosperma

Ferns: Gleichenia dicarpa, Pteridium esculentum, Selaginella uliginosa

Most similar vegetation type: Lowland eastern sedgey buttongrass moorland (Jarman et al. 1988)

This community is defined by the presence of species in groups D-L and the absence of species in the other groups (table 1). Melaleuca squarrosa and $G$. dicarpa are both abundant in this group and largely absent from others. These two species and Gymnoschoenus sphaerocephalus are the most frequent dominants. The community occurs in flat areas along stream lines, where drainage is poor. Trees are sparse or absent. Given a long period without fire $M$. squarrosa could form a closed-scrub on most sites on which this community occurs.

(5) Eucalyptus amygdalina-Acacia melanoxylon-Oxylobium ellipticum open-forest

Trees: Acacia melanoxylon, Eucalyptus amygdalina

Shrubs: Amperea xiphoclada, Aotus ericoides, Leptospermum scoparium, Melaleuca squarrosa, Oxylobium ellipticum, Pimelea linifolia,

Herbs: Stylidium graminifolium

Ferns: Pteridium esculentum

Most similar Statewide vegetation type: Shrubby Eucalyptus amygdalina forest (Duncan \& Brown 1985)

This community is defined by the presence of species in groups $\mathrm{H}, \mathrm{I}, \mathrm{L}$ and $\mathrm{M}$ and the absence of species in other groups (table 1). Acacia melanoxylon and $O$. ellipticum are both abundant in this group and largely absent from others. $E$. amygdalina and, to a lesser extent, E. obliqua, E. viminalis and $E$. ovata form a tall tree layer, below which there is a sparser short tree layer dominated by Acacia melanoxylon. The ground stratum is a depauperate heath. The community occurs on usually well-drained sites on deep, infertile sand in situations where moisture is augmented by downslope flow.

(6) Eucalyptus viminalis-E. amygdalina-Senecio spp. openforest

Trees: Eucalyptus viminalis, E. amygdalina

Shrubs: Pimelea linifolia

Herbs: Senecio spp.

Ferns: Pteridium esculentum

Most similar vegetation type: Shrubby Eucalyptus amygdalina forest (Duncan \& Brown 1985)

This community is defined by the presence of species in groups $\mathrm{I}$, and $\mathrm{L}-\mathrm{N}$ and the absence of species in other groups (table 1). E. viminalis and Senecio spp. best define the group. E. viminalis, E. amygdalina and E. ovata dominate the tree canopy in various combinations. There is a sparse taller shrub layer with the ground layer being dominated by a mixture of shrubs, graminoids, herbs and grasses. This community occurs along the Coffee Creek Valley, and is often badly invaded by exotic species.

\section{Vegetation Types}

The mapped vegetation types are described below. Their distributions are shown in figure 2 .

\section{(1) Eucalyptus amygdalina-E. viminalis-E. obliqua shrubby} forest

This unit includes most of floristic communities 5 and 6 , with the exception of areas dominated by $E$. ovata. Its characteristics and environment are described under these floristic communities. In general, it best fits shrubby E. amygdalina forest (Duncan \& Brown 1985) among previously described communities. Small areas within this mapping unit belong to $E$. viminalis-Bedfordia salicinaPultenaea juniperina wet sclerophyll forest and E. obliquaOlearia lirata-P. juniperinawet sclerophyll forest (Kirkpatrick et al. 1988). These wet sclerophyll forest areas were insufficiently extensive to have a good chance of being selected in the random choice of quadrats, and what chance they had failed to be realised.

\section{(2) Eucalyptus ovata shrubby forest}

This unit occurs in the most poorly drained situations within the shrubby forest of floristic communities 5 and 6 . Melaleuca squarrosa is prominent in the understorey. Herbs and grasses occur in the ground layer, which has much bare ground. The most similar recognised community is the grassy E. ovata woodland of Duncan \& Brown (1985).

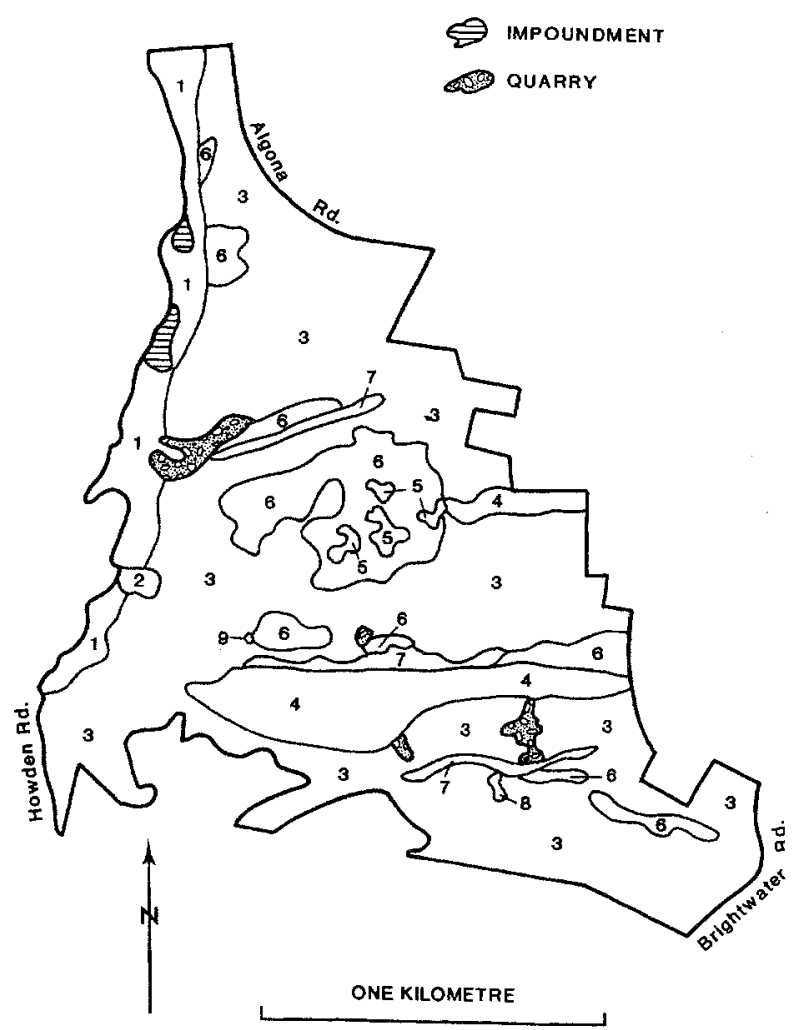

FIG. 2- Natural vegetation map of the Huntingfield Estate. $1=$ Eucalyptus amygdalina-E. viminalis-E. obliqua shrubby forest; 2 = E. ovata shrubby forest; 3 = E. amygdalina heathy coastal forest/woodland; $4=\mathrm{E}$. amygdalina heathy forest on sandstone; $5=$ open heath; $6=$ closed heath; 7 = sedgeland; $8=$ grassland $; 9=$ wetland . 
TABLE 1 .

Sorted table for species occurring in three or more quadrats from the Huntingfield Estate

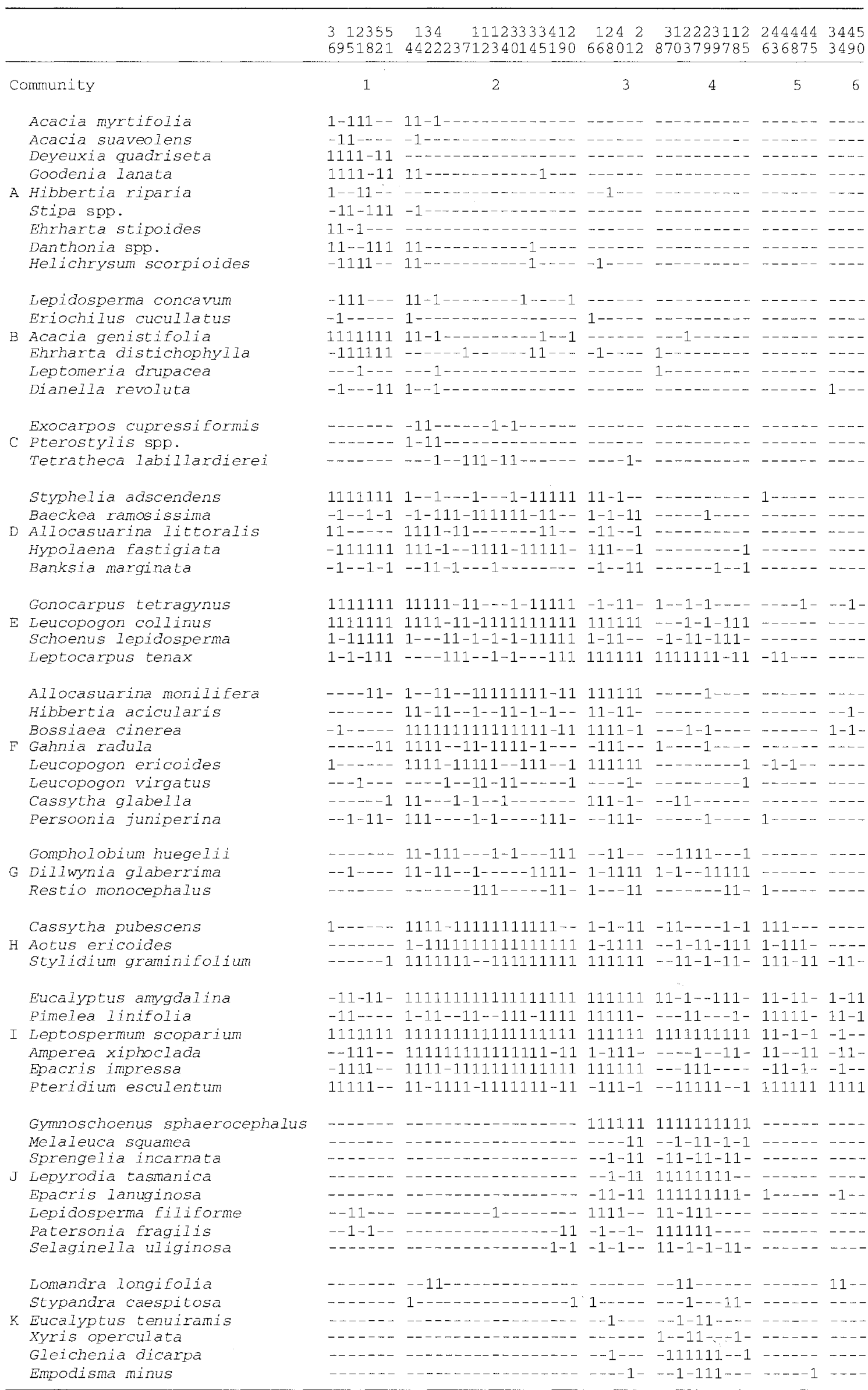


TABLE 1 cont.

\begin{tabular}{|c|c|c|c|c|c|c|c|}
\hline & & $\begin{array}{l}312355 \\
6951821\end{array}$ & $\begin{array}{cr}134 & 11123333412 \\
442223712340145190\end{array}$ & $\begin{array}{r}1242 \\
668012\end{array}$ & $\begin{array}{r}312223112 \\
8703799785\end{array}$ & $\begin{array}{l}244444 \\
636875\end{array}$ & $\begin{array}{l}3445 \\
3490\end{array}$ \\
\hline & Melaleuca squarrosa & ------- & $-------------\cdots---$ & $-11---$ & $111-111111$ & $1111-1$ & $-1-1$ \\
\hline & $\begin{array}{l}\text { Hibbertia procumbens } \\
\text { Boronia parviflora }\end{array}$ & $\begin{array}{l}------ \\
------\end{array}$ & $\begin{array}{l}-------1---------- \\
------------------\end{array}$ & $\begin{array}{l}--1--- \\
------\end{array}$ & $\begin{array}{l}----1- \\
11-\cdots-1--\end{array}$ & $\begin{array}{l}-11--- \\
------\end{array}$ & $\begin{array}{l}--1- \\
-1--\end{array}$ \\
\hline \multirow{6}{*}{ M } & Acacia melanoxylon & ----- & $-------\cdots------$ & ------ & $-\cdots------$ & $11-111$ & $--1-$ \\
\hline & Oxylobium ellipticum & ------- & ----------------- & ----- & $--1------$ & $111--1$ & ---- \\
\hline & * Ulex europaeus & ----- & $--\ldots-------------$ & ------ & --------- & $-11---$ & ---1 \\
\hline & Dianella tasmanica & ------ & $---------\cdots----\cdots---$ & ----- & $--1-\cdots---$ & ----1 & $-1--$ \\
\hline & Eucalyptus ovata & ------- & ------------------ & ------ & $-\cdots--\cdots-\cdots$ & $1-----$ & $-1-1$ \\
\hline & Poa spp. & ------ & $-----------\cdots-----$ & ------ & $-\cdots-\cdots--$ & $---11-$ & $-11-$ \\
\hline \multirow{4}{*}{$N$} & Senecio spp. & ------ & --------------- & ----- & $--\cdots----$ & ------ & $11-1$ \\
\hline & Eucalyptus viminalis & ------ & ------------------ & ------ & ---------- & $1-----$ & 1111 \\
\hline & ${ }^{\star}$ Rubus fruticosus & $1-\cdots---$ & ----------------- & $-\ldots--$ & -------- & $-1----$ & $1--1$ \\
\hline & *Holcus lanatus & $1-\cdots--$ & ----------------- & ------ & $-----\cdots--$ & ----- & $11-$ \\
\hline
\end{tabular}

* Introduced species.

TABLE 2

Vascular plant communities noted from Huntingfield Estate and their reservation status*

\begin{tabular}{|c|c|c|c|c|}
\hline Mappable plant communities ${ }^{\dagger}$ & $\begin{array}{c}\% \text { of } \\
\text { original area } \\
\text { reserved }\end{array}$ & Status ${ }^{\ddagger}$ & Described plant communities $^{\dagger}$ & Status $^{\ddagger}$ \\
\hline Lowland tussock grassland & $<1$ & PR & Eucalyptus viminalis-Bedfordia salicina-Pultenaea & \\
\hline Heath & 15 & WR & juniperina wet sclerophyll forest & PR \\
\hline Buttongrass moorland & 50 & WR & E. obliqua-Olearia lirata-P. juniperina & \\
\hline Enclosed non-glacial wetland & 8 & PR & wet sclerophyll forest & WR \\
\hline Eucalyptus obliqua wet sclerophyll forest & 4 & PR & Lowland eastern sedgey buttongrass moorland & WR \\
\hline Coastal $E$. amygdalina dry sclerophyll forest & 6 & PR & Stipa mollis-Danthonia tussock grassland & UR \\
\hline E. amygdalina dry sclerophyll forest & & & Shrubby $E$. amygdalina forest & WR \\
\hline on sandstone & $<1$ & PR & Shrubby $E$. ovata woodland/forest & UR \\
\hline Inland E. tenuiramis dry sclerophyll forest & $<1$ & PR & Heathy $E$. amygdalina coastal forest & WR \\
\hline \multirow[t]{9}{*}{ E. ovata forest } & $<1$ & PR & Heathy E.amygdalina forest on sandstone & WR \\
\hline & & & Heathy E. tenuiramis forest & PR \\
\hline & & & Sedgey E. amygdalina woodland & WR \\
\hline & & & Shrubby E. obliqua forest & WR \\
\hline & & & $\begin{array}{l}\text { Schoenus lepidosperma-Epacris lanuginosa-Empodisma } \\
\quad \text { minus heath }\end{array}$ & WR \\
\hline & & & Lepidosperma concavum-Cassytha glabella-Gonocarpus & \\
\hline & & & tetragynus heath & WR \\
\hline & & & Lepidosperma longitudinale aquatic sedgeland & WR \\
\hline & & & Stipa mollis-Danthonia setacea grassland & NS \\
\hline
\end{tabular}

\footnotetext{
* Largely derived from Kirkpatrick, J.B. et al. (1995).

${ }^{\dagger}$ Note that $15 \%$ of the original area in secure reserves is used as the criterion for well reserved for mappable communities, whereas substantial areas in two or more viable, secure reserves are required for the well-reserved appellation for described plant communities.

$\ddagger \mathrm{WR}=$ well-reserved, $\mathrm{PR}=$ poorly-reserved, $\mathrm{UR}=$ unreserved, $\mathrm{NS}=$ no information available.
} 
(3) Eucalyptus amygdalina heathy coastal forest/woodland This is the most widespread vegetation type at Huntingfield. The mapping unit corresponds largely with floristic group 2 . $E$. amygdalina dominates the tree stratum, which can be either of forest or woodland density. The eucalypts can be single-stemmed or multistemmed, depending on past disturbance. The ground stratum is a dense heath with a substantial admixture of bracken. Heathy $E$. amygdalina coastal forest (Duncan \& Brown 1985) is the equivalent Statewide community.

(4) Eucalyptus amygdalina heathy forest on sandstone This vegetation type is closely similar structurally and floristically to $E$. amygdalina heathy forest/woodland. However, rocks are generally frequent among the heath understorey, which tends to be sparser than that of community 3. E. tenuiramis and its hybrids with $E$. amygdalina occur as a subdominant in parts of this mapping unit. Heathy E. amygdalina forest on sandstone (Duncan \& Brown 1985) is the equivalent Statewide community.

\section{(5) Open heath}

This relatively sparse heath vegetation corresponds largely with floristic community 1. Acacia genistifolia is the usual dominant and grasses and herbs are prominent beneath. This vegetation type occurs on the less sandy and better drained soils supporting heath. This vegetation type most closely resembles Lepidosperma concavum-Cassytha glabellaGonocarpus tetragynus heath (Kirkpatrick 1977) among recognised Statewide communities.

\section{(6) Closed heath}

This dense heath vegetation is found in poorly drained situations on deep, leached sands. The most typical dominants are Allocasuarina monilifera and Leptospermum scoparium. Many of the quadrats in floristic group 3 fall within this vegetation type, which most closely corresponds to Schoenus lepidosperma-Epacris lanuginosa-Empodisma minus heath (Kirkpatrick 1977) among recognised Statewide communities.

\section{(7) Sedgeland}

This vegetation type largely corresponds with floristic group 4. Details of dominance and environment are given above. It most loosely fits lowland eastern sedgey buttongrass moorland (Jarman et al. 1988) among the recognised Statewide communities. Some of this mapping unit has a sufficient tree stratum to be classifiable as sedgey Eucalyptus amygdalina woodland (Duncan \& Brown 1985).

\section{(8) Grassland}

Some small areas of vegetation dominated by Stipa mollis and Danthonia setacea occur within the open-heath vegetation type, with one area large enough to map. This may be a degradation stage rather than a stable community as it occurs along roadsides where clay is close to the surface. It falls within floristic group 1

\section{(9) Wetland}

The one small, natural enclosed wetland in the estate is dominated by Lepidosperma longitudinale. Restio complanatus also occurs in this species poor vegetation type. The margin of the wetland is dominated by Melaleuca squamea and $M$. squarrosa. L. longitudinale aquatic sedgeland is the Statewide community best pertaining to this wetland. Artifical wetlands have been created by the damming of Coffee Creek. These are described by Duncan \& Duncan (1995).

\section{CONSERVATION STATUS OF PLANT COMMUNITIES AND SPECIES}

Nine communities that are mappable on a statewide basis were located in the Huntingfield Estate (table 2). Of these communities only heath and buttongrass moorland were reserved at a level considered to be satisfactory (more than 15\% of pre-European occurrence) in 1995 (Kirkpatrick et al. 1995). The remaining communities were poorly-reserved. Two of these, lowland tussock grassland and Eucalyptus ovata forest, have had most of their original area destroyed by land clearance and cultivation. These two communities occupy only a small proportion of the estate (fig. 2).

Of the described but non-mappable communities (those based on floristic combinations and combinations of understorey and overstorey dominance), fourteen were recognised from the estate (table 2). Stipa mollis-Danthonia tussock grassland (a previously undescribed community) and shrubby Eucalyptus ovata woodland/forest were not known from any secure reserve in the State in 1995. Heathy $E$. tenuiramis forest was poorly reserved, only being known from the Coal River Gorge Nature Reserve. E. viminalisBedfordia salicina-Pultenaea juniperina wet sclerophyll forest was also poorly reserved. The remaining communities were considered well reserved, in that they occur in viable areas in two or more secure reserves.

The recent land-use decisions made as a result of the Regional Forest Agreement Process, including the establishment of the Peter Murrell Nature Reserve within the study area, have resulted in a more secure conservation status for all the unreserved and poorly reserved communities indicated above. The Peter Murrell Nature Reserve contains areas of all these communities, and other secure reserves promised, or possible, under the agreement might further improve their reservation status.

Several species of conservation significance occur within the estate. Prasophyllum concinnum is an orchid which, at one time, was thought to be extinct, but was recently found within the estate (Ziegeler 1994). It has also recently been found in two secure reserves elsewhere in the State. Its status is now considered to be rare, rather than endangered. Other State-listed rare vascular plant species (Threatened Species Act 1997) found within the estate are Caladenia alata, which was also unreserved, Juncus amabilis and Restio monocephalus. The latter species is very common in the estate in heath and on the margins of buttongrass moorland.

A moss, Archidium stellatum, has been only recorded from the estate within Tasmania. However, this identification needs to be verified. Another moss found in the estate, Breutelia affinis, is poorly reserved within Tasmania (Moscal \& Kirkpatrick 1997).

\section{MANAGEMENT PROBLEMS}

Small-scale open spaces are an important component of the local environment, especially in the vicinity of otherwise dense gound vegetation. The open spaces are important in maintaining the rich orchid flora of the estate. Consequently, some thought needs to be given to the processes which generate and maintain the multi-scale mosaic of these spaces. 
In other parts of Tasmania, burrowing mammals, ant nests, fluctuating water tables, small-scale fires and local disease outbreaks variously contribute to this dynamic. In Huntingfield, periodically slashed fire breaks appear to have promoted the abundance of native orchids, including Prasophyllum concinnum.

Most of the 64 exotic plants found in the estate are confined to places that have been subject to nutrient addition and substantial ground disturbance or are naturally more fertile than the leached sands that cover most of the study area. The exotic species have the greatest cover in the Coffee Creek valley and where shellfish have been cleaned, leaving large European middens (fig. 3).

The exotic plant species that most threaten the integrity of the natural vegetation are a group of fire-adapted shrubs. These include two Australian native shrubs that do not occur naturally in southern Tasmania, Acacia longifolia and $A$. retinodes. Both produce hard-coated seeds in profusion. These seeds have their germination stimulated by fire. A group of introduced pea shrubs, Chamaecytisus proliferus, Cytisus scoparius, Psoralea pinnata and Genista monspessulana, are also adapted to store seeds in the soil and germinate prolifically after fire. Gorse (Ulex europaeus) not only does the same but also makes outstanding vegetative recovery. South African boneseed (Chrysanthemoides monilifera) is easily killed by fire but germinates profusely after it, and, unlike the previous species, is widely dispersed by birds who value the fleshy coating of its hard seed. Spanish heath (Erica lusitanica) while not having a wide dispersal range, spreads vegetatively, resprouts vigorously and germinates prolifically after fire. Pampas grass (Cortaderia selloana) resprouts after fire and has seed that is spread widely by wind. It is the most threatening of the herbaceous plants.

With the exception of Spanish heath and isolated individuals of pampas grass, the above species are confined to the open forest along Coffee Creek or to the disturbed areas behind houses on the eastern boundary. Spanish heath has established in relatively small numbers within the largest area of heath, where there are also small infestations of the bird-dispersed and fire-resistant blackberry (Rubus fruticosus).

Although most of the threatening exotic species are found in low numbers within the interior of the surviving bush, all, with the possible exception of blackberry, have the potential for exponential growth in numbers in the well drained part of the area. Pampas grass may be able to invade the poorly drained parts.

Many of these species, and some that are yet to invade the area, grow in the domestic gardens that partially abut the bush now and are likely to surround the bush in the future. It is important that invasive species are excluded from domestic horticulture within dispersal range, which is up to $400 \mathrm{~m}$ in the case of bird-dispersed species (Zacharek 1990).

Phytophthora cinnamomi, the cinnamon fungus, is a rootrotting exotic widespread in heaths and heathy woodland in lowland Tasmania (Podger et al. 1990). Localised dieback of the susceptible species, Sprengelia incarnata, and other epacrids, indicate its widespread presence in the area. It seems to be too late to take any action to prevent its spread.

Fire is a management problem in two ways. Firstly, the frequency of fire can be such that native species are threatened. This can happen with too frequent fire, when obligate seed regenerators, such as Leptospermum glaucescens, can be eliminated. Alternatively, too infrequent fire may

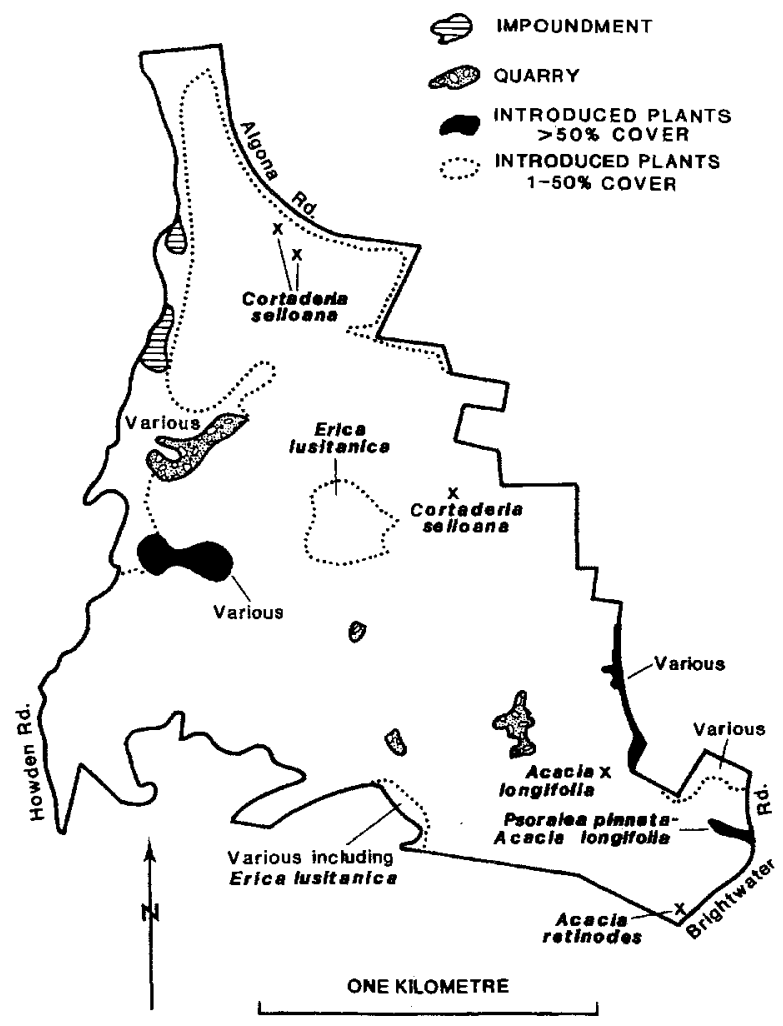

FIG. 3- The distribution of environmental weed infestations in the Huntingfield Estate.

reduce or eliminate many of the smaller species, such as orchids, as the dominant shrubs form a closed canopy. Secondly, fire is a management problem, in that fires lit within bush on blowup days can threaten adjacent property. This creates a management imperative to minimise the chances of that spread. This means reducing fuel, at least on the boundaries, using fire or mechanical means.

While the ecological impacts of varying fire frequencies on heathy vegetation are not fully understood, recommended burning intervals tend to be between ten and 30 years. The rarity of L. glaucescens in Huntingfield tends to suggest that fires have been much more frequent than once every ten years over most of the estate.

It is considered to be important for biodiversity conservation in bush islands, the likely future of Huntingfield, that fires do not burn the whole area at once. This implies a patch burning strategy.

The fuel accumulation characteristics of heathy vegetation are such that fuel levels that could be dangerous to adjacent properties will accumulate if the ecologically acceptable frequencies are adopted. However, the major danger to property is high fuel levels close to houses. Thus, fuel reduction is largely a matter pertaining to the margins of the area.

Accessions of water and nutrients in heathy ecosystems have been shown to lead to deterioration in the native vegetation and invasion of exotic plants. Such accessions already occur where houses are in the upper parts of catchments, although their magnitude appears to be relatively small. Capture of drainage in sewerage systems or on domestic blocks will be necessary if there is not to be further down-catchment damage.

The dumping of rubbish is another major source of nutrients. The dumping of garden waste is particularly 
dangerous as it combines nutrition with dispersal of potentially invasive species.

The area is used for the extraction of firewood, sand and native plants, all informally and illegally. The extraction of firewood is associated with the movement of vehicles off tracks, causing damage to soils and understorey vegetation.

As the only large area of accessible and effectively uncontrolled bush near the suburbs of Kingston and Blackmans Bay, Huntingfield is a playground for horseriders, off-road vehicle enthusiasts, mountain bikers, dog walkers, walkers, runners and shooters. Juvenile trail-bikers are particularly numerous. The map of tracks in the area (fig. 4) may not include all of the large number of narrow bike trails that link the bulldozed lines, as these are not always perceptible on the aerial photographs. Mechanised recreationalists have caused a large amount of damage to the natural ecosystems of the area, particularly where they cross drainage lines.

\section{GENERAL DISCUSSION}

The Huntingfield area has a flora and vegetation with a high degree of similarity to other areas with infertile, sandy soils and similar rainfall elsewhere in the State, such as Lime Bay on the Tasman Peninsula (Kirkpatrick 1975) and the granitic country of the northeast of the State (Duncan \& Brown 1995). However, its suburban situation presents a degree of difficulty in management well above that in similar areas, such as the Lime Bay Nature Reserve and the Mount William National Park. Nevertheless, this situation is an advantage in the process of educating the public on the values of the heathy ecosystems of Tasmania, as this is the closest area of such vegetation to a major population centre.

The native vegetation of the area should be able to persist in at least its present state of health in the long term, if substantial additions of nutrients to the soils can be avoided and control of potentially transforming weeds can be achieved. Neither of these requirements should be daunting tasks, especially if the present level of community involvement in management can be maintained.

\section{ACKNOWLEDGEMENTS}

Much of this work was done for the Huntingfield/Coffee Creek Landcare Group and was supported by a Save the Bush grant. The 1996 Vegetation Management class at the University of Tasmania helped collect much of the data. Andrew Zacharek and Mona Loofs also helped in the collection of the quadrat data. We are grateful to Hans Wapstra for information on orchid species distribution and Pieter van der Meer for access to his list of species of the Blackmans Bay area. Tony Moscal kindly collected and identified moss and liverwort species from the area. Guus van de Geer drew the figures.

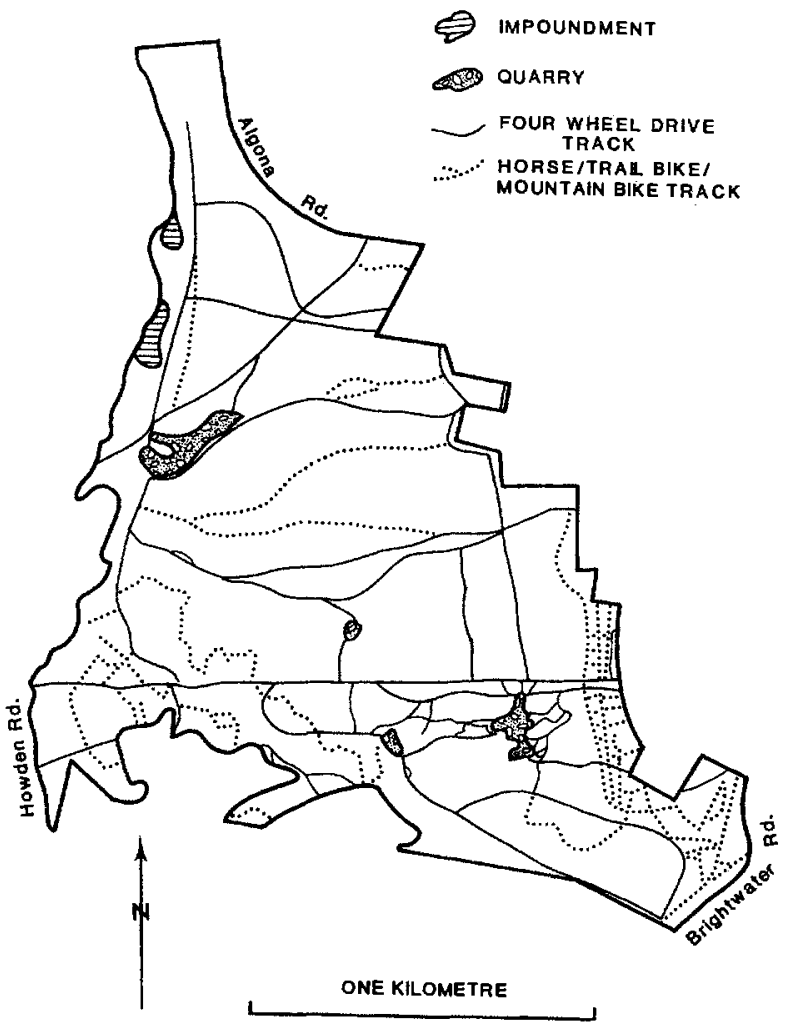

FIG. 4 - Tracks in Huntingfield.

\section{REFERENCES}

BUCHANAN, A.M., 1995: A CENSUS OF THE VASCULAR PLANTS OF TASMANIA. Tasm. Herb. Occ. Publ. 5. Tasmanian Herbarium, Hobart.

DUNCAN, F. \& Brown, M.J., 1985: DRY SCLEROPHYLL VEGETATION IN TASMANIA. Wildl. Div. Tech. Rep. 85/1. National Parks \& Wildlife Service, Tasmania.

DunCan, F. \& Brown, M.J., 1995: Edaphics and fire - an interpretative ecology of lowland forest vegetation on granite in northeast Tasmania. Proc. Linn. Soc. NSW 115: 45-60.

DUNCAN, D. \& DUNCAN, F., 1995: Vegetation resources and management in the Coffee Creek Reserve and the Huntingfield Estate. Report to the Huntingfield/Coffee Creek Landcare Group.

Flora Advisory CouncIL, 1994: NATIVE HIGHER PLANT TAXA WHICH ARE RARE OR THREATENED IN TASMANIA. Parks \& Wildlife Service, Hobart.

HILL, M.O., 1979: TWINSPAN: A FORTRAN program for arranging multivariate data in an ordered two-way table by classification of the individuals and attributes. Cornell University, New York.

Jarman, S.J., Kantvilas, G. \& Brown, M.J., 1988: BUTTONGRASS MOORLAND IN TASMANIA. Res. Rep. 2. Tasmanian Forest Research Council Inc.

Kirkpatrick, J.B., 1975: Phytosociological analysis of the vegetation of Lagoon Beach, Tasmania. Pap. Proc. R. Soc. Tasm. 109: 530-563.

KIRKPATRICK, J.B., 1977: THE DISAPPEARING HEATH. Tasmanian Conservation Trust, Hobart.

KirkPATRICK, J.B. \& Brown, M.J., 1991: RESERVATION ANALYSIS OF TASMANIAN FORESTS. Resource Assessment Commission Forest and Timber Inquiry Consultancy Series FTC91/16: $131 \mathrm{pp}$.

KirkPatrick, J.B. \& DiCKINSON, K.J.M., 1984. VEGETATION MAP OF TASMANIA, 1:500,000. Forestry Commission, Tasmania. 
Kirkpatrick, J.B. \& Dickinson, K.J.M., 1986: Achievements, conflicts and concepts in Australian small-scale vegetation mapping. Aust. Geogr. Stud. 24: 224-234.

Kirkpatrick, J.B., Peacock, R.J., Cullen, P.J. \& Neyland, M.G., 1988: THE WET EUCALYPT FORESTS OF TASMANIA. Tasmanian Conservation Trust, Hobart.

Kirirpatrick, J.B., Barker, P., Brown, M.J., Harris, S. \& Mackie, R., 1995: THE RESERVATION STATUS OF TASMANIAN VASCULAR PLANT COMMUNITIES. Wildl. Sci. Rep. 95/4. Parks \& Wildlife Service, Tasmania.

MosCal, A. \& KrrKPatrick, J.B., 1997: ATIAS OF MOSSES AND LIVERWORTS IN TASMANIA. A report to the Australian Heritage Commission from the Tasmanian Conservation Trust.

Mueller-Dombois, D. \& Ellenberg, H.,1974: AIMS AND METHODS OF VEGETATION ECOLOGY. Wiley International, New York.
Podger, F., Palzer, C. and Wardlaw, T., 1990: A guide to the Tasmanian distribution of Phytophthora cinnamomi and its effects on native vegetation. Tasforests 2: 13-20.

PYRKE, A., 1990: Report on a botanical survey of the Coffee Creek area in the proposed Huntingfield development. Department of Geography and Environmental Studies, University of Tasmania.

ZACHAREK, A., 1990: Bush invasion by Cotoneasterspp, in Hobart. Unpubl. Grad.Dipl.Env.Stud. (Hons) thesis, Univ. Tasm.

ZIEGELER, D., 1994: PRASOPHYLLUM CONCINNUM FLORA RECOVERY PLAN - MANAGEMENT PHASE. Wildl. Rep. 94/11. Parks \& Wildlife Service, Tasmania.

(accepted 5 July 1999)

\section{APPENDIX 1}

Species of vascular plant, mosses and liverworts observed in the Huntingfield Estate (nomenclature after Buchanan 1995)

ANGIOSPERMAE
DICOTYLEDONAE
Apiaceae
Xanthosia dissecta
Asteraceae
${ }^{*}$ Arctotheca calendula
${ }^{\dagger}$ Bedfordia salicina
${ }^{*}$ Bellis perennis
${ }^{\dagger}$ Brachyscome spathulata ssp. glabra
Cassinia aculeata
${ }^{*}$ Cirsium vulgare
${ }^{*}$ Chrysanthemoides monilifera
Chrysocephalum apiculatum
Cotula coronopifolia
Gnaphalium collinum
Helichrysum scorpioides
${ }^{*}$ Hypochoeris radicata
${ }^{*}$ Leontodon taraxacoides
Leptinella reptans
Leptorhynchos squamatus
Olearia myrsinoides
O. phlogopappa
O. ramulosa
Ozothamnus ferrugineus
${ }^{*}$ Picris echioides
Senecio hispidulus
S. linearifolius
S. minimus
S. quadridentatus
${ }^{*}$ S. vulgaris
${ }^{*}$ Sonchus asper
${ }^{*}$ S. oleraceus
${ }^{*}$ Taraxacum officinale
*Vellereophyton dealbatum
Brassicaceae
*Rorippa nasturtium-aquaticum
Callitrichaceae
*Callitriche stagnalis
Campanulaceae
Lobelia gibbosa
Wablenbergia sp.

Caryophyllaceae

* Cerastium glomeratum

* Moenchia erecta

* Sagina procumbens

* Spergula arvensis

* Stellaria media

*S. pallida

Casuarinaceac

Allocasuarina littoralis

A. monilifera

Clusiaceae

Hypericum gramineum

Crassulaceae

Crassula sieberana

Dilleniaceae

Hibbertia acicularis

$H$. procumbens

H. riparia

Droseraceae

Drosera peltata ssp. auriculata

D. peltata ssp. peltata

D. pygmaea

Epacridaceae

Astroloma humifusum

Epacris impressa

E. Lanuginosa

E. obtusifolia

Leucopogon collinus

L. ericoides

L. virgatus

Sprengelia incarnata

Styphelia adscendens

Ericaceae

* Erica lusitanica

Euphorbiaceae Amperea xiphoclada

Fabaceae

Aotus ericoides

Bossiaea cinerea

B. prostrata

${ }^{*}$ Chamaecytisus proliferus
${ }^{*}$ Cytisus scoparius

Daviesia ulicifolia

Dillwynia glaberrima

* Genista monspessulana Gompholobium huegelii

* Lotus pedunculatus

Oxylobium ellipticum

* Psoralea pinnata

Pultenaea dentata

P. juniperina

Sphaerolobium minus

*Trifolium dubium

*T. repens

* Ulex europaeus

*Vicia sativa

Fumariacae

* Fumaria muralis

Gentianaceae

${ }^{*}$ Centaurium erythraea

Geraniaceae Geranium potentilloides

Goodeniaceae

Goodenia lanata

Haloragaceae

Gonocarpus micranthus

$G$. tetragynus

G. teucrioides

Lamiaceae

*Prunella vulgaris

Lauraceae

Cassytha glabella

C. pubescens

Lentibulariaceae

Utricularia dichotoma

$U$. lateriflora

Loganiaceae

Mitrasacme pilosa

Mimosaceae

Acacia dealbata

A. genistifolia

${ }^{*}$ A. longifolia 
APPENDIX 1 cont.

\begin{tabular}{|c|c|c|}
\hline Mimosaceae (cont.) & Stylidiaceae & C. reflexa \\
\hline A. melanoxylon & Stylidium graminifolium & Diuris pardina \\
\hline A. myrtifolia & Thymeleaceae & D. sulphurea \\
\hline *Acacia retinodes & Pimelea bumilis & Eriochilus cucullatus \\
\hline A. stricta & $P$. linifolia & Genoplesium archeri \\
\hline A. suaveolens & Tremandraceae & Glossodia major \\
\hline A. verticillata & Tetratheca labillardierei & Microtis arenaria \\
\hline Myrtaceae & T. pilosa & M. unifolia \\
\hline Baeckea ramosissima & Violaceae & Paracaleana minor \\
\hline Callistemon pallidus & Viola cleistogamoides & ${ }^{\dagger}$ Prasophyllum concinnum $\mathrm{R} 2$ \\
\hline${ }^{\dagger}$ Eucalyptus amygdalina & & Pterostylis apbylla \\
\hline E. obliqua & MONOCOTYLEDONAE & P. nana \\
\hline E. ovata & Centrolepidaceae & P. nutans \\
\hline${ }^{\dagger} E$. tenuiramis & Centrolepissp. & P. parviflora \\
\hline E. viminalis & Cyperaceae & P. plumosa \\
\hline${ }^{\dagger}$ Leptospermum glaucescens & Baumea acuta & Thelymitra arenaria \\
\hline L. scoparium & B. tetragona & T. aristata \\
\hline Melaleuca squamea & Carex appressa & T. cyanea \\
\hline M. squarrosa & Gahnia grandis & T. ixioides \\
\hline Onagraceae & G. radula & T. nuda \\
\hline Epilobium hirtigerum & Gymnoschoenus sphaerocephalus & T. pauciflora \\
\hline Oxalidaceae & Isolepis cernua & T. rubra \\
\hline Oxalis perennans & I. inundata & T. venosa \\
\hline Pittosporaceae & I. nodosa & Poaceae \\
\hline Bursaria spinosa & Lepidosperma concavum & * Agrostis capillaris \\
\hline Plantaginaceae & L. elatius & A. sp. \\
\hline *Plantago coronopus & L. filiforme & *Aira caryopbyllea \\
\hline${ }^{*} P$. lanceolata & L. gunnii & *Alopecurus geniculatus \\
\hline Polygonaceae & L. laterale & *Anthoxanthum odoratum \\
\hline *Acetosella vulgaris & L. longitudinale & ${ }^{*}$ Bromus diandrus \\
\hline${ }^{*}$ Rumex crispus & Schoenus apogon & ${ }^{*} B$. sterilis \\
\hline Polygalaceae & S. lepidosperma & * Cortaderia selloana \\
\hline Comesperma volubile & Tetraria capillaris & * Dactylis glomerata \\
\hline Portulacaceae & Iridaceae & Danthonia pilosa \\
\hline * Calandrinia caulescens & Diplarrena moraea & D. setacea \\
\hline Primulaceae & Patersonia fragilis & Deyeuxia quadriseta \\
\hline${ }^{*}$ Anagallis arvensis & Juncaceae & Dichelachne crinita \\
\hline Proteaceae & ${ }^{\ddagger} J u n c u s$ amabilis $\mathrm{R} 2 \mathrm{UR}$ & D. sp. \\
\hline Banksia marginata & *J. articulatus & Ehrharta acuminata \\
\hline${ }^{\dagger}$ Lomatia tinctoria & ${ }^{*} J$. effusus & E. distichophylla \\
\hline Persoonia juniperina & J. gregiflorus & E. stipoides \\
\hline Ranunculaceae & J. pallidus & Elymus scaber \\
\hline Clematis aristata & J.procerus & * Glyceria declinata \\
\hline${ }^{*}$ Ranunculus muricatus & J. sarophorus & ${ }^{*}$ Holcus lanatus \\
\hline Rosaceac & Luzula flaccida & *Poa annua \\
\hline Acaena novae-zelandiae & Liliaceae & P. labillardierei \\
\hline${ }^{*}$ Crataegus monogyna & Dianella revoluta & P. sieberiana \\
\hline${ }^{*}$ Rosa rubiginosa & D. tasmanica & Stipa flavescens \\
\hline${ }^{*}$ Rubus fruticosus & Drymophila cyanocarpa & S. mollis \\
\hline Rubiaceae & Thelionema caespitosum & ${ }^{*}$ Vulpia bromoides \\
\hline${ }^{*}$ Galium aparine & Orchidaceac & ${ }^{*} V$. megalura \\
\hline Opercularia varia & ${ }^{\ddagger}$ Caladenia alata R2 UR & Restionaceae \\
\hline * Sherardia arvensis & ${ }^{\dagger}$ C. atrata & Empodisma minus \\
\hline Rutaceae & C. carnea aff. fuscata & Hypolaena fastigiata \\
\hline Boronia parviflora & C. clavigera & Leptocarpus tenax \\
\hline Zieria arborescens & C. dilatata & Lepyrodia muelleri \\
\hline Salicaceae & C. gracilis & L. tasmanica \\
\hline * Salix babylonica & C. patersonii & Restio complanatus \\
\hline Santalaceae & Caleana major & ${ }^{\ddagger} R$. monocephalus R2 \\
\hline Exocarpos cupressiformis & Calochilus herbaceus & Typhaceae \\
\hline Leptomeria drupacea & C. paludosus & ${ }^{*}$ Typha orientalis \\
\hline Stackhousiaceae & C. robertsonii & Xanthorrhoeaceae \\
\hline Stackhousia monogyna & Chiloglottis gunnii & Lomandra longifolia \\
\hline
\end{tabular}


APPENDIX 1 cont.

\begin{tabular}{|c|c|c|}
\hline Xyridacaee & BRYOPHYTA & Polytrichaceae \\
\hline${ }^{\dagger}$ Xyris gracilis ssp. tasmanica & Archidiaceae & Polytrichum juniperinum var. australe \\
\hline${ }^{\dagger} X$ marginata & ${ }^{\ddagger}$ Archidium stellatum UR & Pottiaceae \\
\hline \multirow{2}{*}{$X$. operculata } & Aulicomniaceae & Barbula calycina \\
\hline & Leptotheca gaudichaudii var. gaudichaudii & B. crinita \\
\hline PTERIDOPHYTA & Bartramiaceae & Didymodon australasiae \\
\hline Aspidaceae & ${ }^{\ddagger}$ Breutelia affinis $\mathrm{PR}$ & Gymnostomum calcareum \\
\hline Polystichum proliferum & Bryaceae & Tortula muralis \\
\hline Aspleniaceae & Bryum argenteum & Triquetrella papillata \\
\hline Asplenium flabellifolium & B. caespiticium & Sphagnaceae \\
\hline Blechnaceae & B. dichotomum & Sphagnum australe \\
\hline Blechnum minus & B. pachytheca & S. cristatum \\
\hline B. nudum & Dicranaceae & \\
\hline B. wattsii & Campylopus clavatus & HEPATICA \\
\hline Dennstaedtiaceae & C. introflexus ssp. pudicus & Acrobolbaceae \\
\hline Pteridium esculentum & Ditrichaceae & Goebelobryum unguiculatum \\
\hline Dicksoniaceae & Ceratodon purpureus & Lethocolea squamata \\
\hline Dicksonia antarctica & Ditrichum cylindricarpum & Cephaloziellaceae \\
\hline Gleicheniaceae & D. difficile & Cephaloziella exiliflora \\
\hline Gleichenia dicarpa & Fissidentaceae & Geocalycaceae \\
\hline Lindsaeaceae & Fissidens leptocladus & Chiloscyphus semiteres var. semiteres \\
\hline Lindsaya linearis & Funariaceae & Heteroscyphus coalitus \\
\hline Schizeaceae & Funaria hygrometrica & H. varians \\
\hline Schizaed sp. & Grimmiaceae & Lepidozoaceae \\
\hline Selaginellaceae & Grimmia pulvinata & Hyalolepidozia longiscypha \\
\hline Selaginella uliginosa & Hookeriaceae & Kurzia compacta \\
\hline & Calyptrochaeta apiculata & Lepidozia laevifolia \\
\hline & Orthotrichaceae & Marchantiaceae \\
\hline & Zygodon menziesii & Lunularia cruciata \\
\hline
\end{tabular}

* Introduced species.

$\dagger$ Tasmanian endemic species.

₹ R2 = rare in Tasmania (Flora Advisory Committee 1994). UR = not known to occur in any other secure reserve. PR = poorly-reserved (only known to occur in one population in one other secure reserve). 